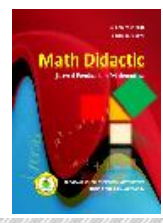

MATH DIDACTIC: JURNAL PENDIDIKAN MATEMATIKA

Volume 4 Nomor 3, September - Desember 2018, halaman 169 - 179

Tersedia Daring pada http://jurnal.stkipbjm.ac.id/index.php/math

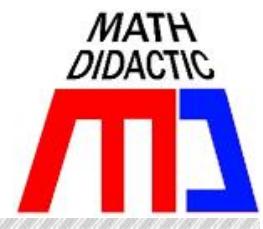

\title{
PENERAPAN MODEL PEMBELAJARAN ARIAS \\ UNTUK MENINGKATKAN KEMAMPUAN PENALARAN MATEMATIS MAHASISWA PADA MATA KULIAH ANALISA REAL
}

\author{
THE APPLICATION OF MODEL LEARNING ARIAS \\ TO IMPROVE STUDENTS 'MATHEMATICAL REASONING IN REAL ANALYSIS
}

\author{
Arfatin Nurrahmah, Abdul Karim \\ Universitas Indraprasta PGRI Jakarta \\ arfatin.nurrahmah@unindra.ac.id, abdul_karim@unindra.ac.id
}

\begin{abstract}
Abstrak: Tujuan penelitian ini untuk mengetahui peningkatan kemampuan penalaran matematis mahasiswa pada mata kuliah analisa real melalui model pembelajaran ARIAS. Metode penelitian yang digunakan adalah Penelitian Tindakan Kelas (PTK) yang dilakukan secara kolaboratif dan bersiklus. Penelitian ini terdiri dari dua siklus dan masing-masing siklus terdiri dari empat tahapan, yaitu perencanaan, tindakan, analisis, dan refleksi. Subjek penelitian adalah mahasiswa semester 6 pendidikan matematika UNINDRA PGRI tahun akademik 2017/ 2018 sejumlah 30 orang. Untuk mengecek keabsahan data, peneliti menggunakan sistem triangulasi, yaitu salah satu cara dalam mengumpulkan serta menyimpulkan data dengan hasil pengamatan tiga pihak yaitu: mahasiswa, peneliti dan observer. Hasil dari penelitian ini adalah penerapan model pembelajaran ARIAS dalam mata kuliah analisa real dengan menerapkan lima komponen yang saling terkait dan menguatkan satu sama lain, yaitu Assurance, Relevance, Interest, Assesment, dan Satisfaction, dapat meningkatkan kemampuan penalaran matematis mahasiswa pada mata kuliah analisa real. Hal ini dapat dilihat dari peningkatan nilai rata-rata tes kemampuan penalaran matematis pada penelitian pendahuluan hingga siklus II. Pada tes pendahuluan rata-rata kemampuan penalaran matematis adalah 60,50, pada siklus I rata-rata kemampuan penalaran matematis adalah 73,07, siklus II rata-rata kemampuan penalaran matematis mengalami peningkatan menjadi 82,43.
\end{abstract}

Kata Kunci: Model Pembelajaran ARIAS, Kemampuan Penalaran Matematis, Analisa Real

\begin{abstract}
The purpose of this study was to determine the improvement of students' mathematical reasoning ability in the real analysis subject through the ARIAS learning model. The research method used is Classroom Action Research which is carried out collaboratively and cycles. This study consists of two cycles and each cycle consists of four stages, namely planning, action, analysis, and reflection. Research subjects were 6th semester students of mathematics education at UNINDRA PGRI 2017/2018 academic year totaling 30 people. To check the validity of the data, the researcher used a triangulation system, which is one way to collect and conclude data with the observations of three parties: students, researchers and observers. The results of this study are the application of ARIAS learning models in real analysis courses by applying five components that are interrelated and reinforce each other, namely Assurance, Relevance, Interest, Assessment, and Satisfaction, can improve students' mathematical reasoning skills in real analysis subjects. This can be seen from the increase in the average value of a mathematical reasoning ability test in the preliminary research until the second cycle. In the preliminary test the average mathematical reasoning ability is 60.50, in the first cycle the average mathematical reasoning ability is 73.07, the second cycle the average mathematical reasoning ability has increased to 82.43 .
\end{abstract}

Keywords: Model Learning Mathematical Reasoning Ability, ARIAS, Real Analysis

Cara Sitasi: Nurrahmah, A., \& Karim, A. (2018). Penerapan model pembelajaran ARIAS Untuk meningkatkan kemampuan penalaran matematis mahasiswa pada mata kuliah analisa real. Math Didactic: Jurnal Pendidikan Matematika, 4(3), 169-179. 
Pendidikan adalah suatu cara untuk mengembangkan keterampilan, kebiasaan dan sikap yang diharapkan dapat membuat seseorang menjadi warga negara yang baik. Pendidikan juga mempunyai pengertian usaha sadar yang teratur dan sistematis yang dilakukan oleh orang tua yang diberi tanggung jawab untuk mempengaruhi anak agar mempunyai sifat-sifat dan karakter yang sesuai dengan cita-cita pendidikan. Karakter yang baik akan membantu peserta didik dalam menghadapi tantangan global (Karim, 2018, hal 1). Dari sini bisa kita maknai bahwa pendidikan merupakan faktor strategis dalam menciptakan kemajuan suatu bangsa. Pendidikan yang berkualitas menghasilkan sumber daya manusia yang berkualitas dan produktif. Berhasil tidaknya pencapaian tujuan pendidikan sangat dipengaruhi oleh proses belajar yang dialami oleh mahasiswa.

Dalam pembelajaran matematika salah satu hambatan yang dihadapi adalah kurangnya rasa ketertarikan terhadap mata pelajaran tersebut (Karim dan Nurrahmah, 2018, hal. 98). Banyak kalangan mahasiswa yang menganggap belajar di kelas adalah hal yang kurang menyenangkan, duduk berjamjam mendengarkan dosen menyampaikan materi perkuliahan berdasarkan referensi yang telah diberikan serta pengerjaan tugas demi mendapatkan nilai. Kegiatan konvensional ini biasa dihadapi mahasiswa setiap harinya, sehingga mahasiswa menganggap perkuliahan hanya sebuah rutinitas untuk mendapatkan nilai tanpa diimbangi dengan kesadaran bahwa kuliah bertujuan untuk menambah pengetahuan baru dengan memanfaatkan pengetahuan yang sudah didapat pada jenjang sebelumnya. Pengetahuan sebelumnya ini dapat bermanfaat untuk memecahkan suatu permasalahan sehingga mendapatkan informasi baru. Dengan anggapan perkuliahan hanya mendapatkan nilai saja, akan mengakibatkan mahasiswa menjadi pasif dan proses pembelajaran kurang efektif.

Analisa real merupakan salah satu mata kuliah wajib yang diberikan pada mahasiswa di jurusan maupun program studi matematika dan pendidikan matematika. Melalui mata kuliah analisa real, diharapkan dapat menjangkau ranah kognitif tingkat tinggi dalam pembelajaran matematika. Teori matematika khususnya yang menyangkut himpunan bilangan real dan fungsi-fungsi yang didefinisikan pada himpunan bilangan real dibahas secara hierarki dan ketat dalam analisa real (Hernadi, 2015, hal. 7). Mata kuliah analisa real dapat menjadi wadah untuk melatih kemampuan penalaran mahasiswa. Tujuan dari mata kuliah analisa real adalah untuk melakukan penyelidikan yang mendalam terhadap masalah matematika yang melibatkan bilangan real. Di tingkat perguruan tinggi, pembelajaran matematika lebih menekankan pada pembentukan pola pikir matematika yang logis dan kritis. Jadi bukan lagi menerapkan kemampuan berhitung semata. Melalui mata kuliah analisa real ini, mahasiswa diharapkan dapat mengasah pola pikirnya melalui ketekunan dalam mempelajari langkah demi langkah berbagai aksioma, definisi, maupun teorema-teorema yang berkaitan dengan bilangan real.

Mata Kuliah analisis real mempunyai bobot 3 SKS dan diberikan pada mahasiswa matematika semester 6. Berdasarkan pengalaman mengajar mata kuliah analisis real di Program Studi Pendidikan Matematika selama hampir 3 tahun, masih banyak mahasiswa yang menganggap analisa real adalah mata kuliah yang sulit. Hal ini terlihat dari rendahnya nilai mahasiswa pada ujian akhir semester dan mendapat nilai C (56-62). Rendahnya nilai mahasiswa kemungkinan disebabkan karena analisa real berbeda dari 
cabang matematika lainnya, karena analisa real memiliki tingkat abstrak yang sangat tinggi. Hal ini mengakibatkan mahasiswa membutuhkan kemampuan penalaran yang baik. Namun pada kenyataannya, kebiasaan pembelajaran matematika di sekolah menengah yang selama ini menekankan pada aspek kemampuan berpikir mekanistik (algorithm thingking) daripada aspek kemampuan berpikir logis (logically thingking) menyebabkan lemahnya kemampuan bernalar mahasiswa (Hernadi, 2015, hal. 8). Hal tersebut berdampak terhadap nilai yang tidak optimal. Hal ini sejalan dengan penelitian Sucipto dan Mauliddin (2016, hal. 200 ) tentang kesulitan mahasiswa dalam belajar analisa real mencangkup hal-hal berikut, yakni: mahasiswa sulit merespon apa maksud dan tujuan soal, sulit menentukan awal atau permulaan dari suatu pembuktian, sulit menemukan ide dan gagasan, sulit menerapkan definisi, sifat, maupun teorema dalam mengkonstruksi pembuktian, dan mahasiswa masih sulit berpikir logis menentukan langkah-langkah pembuktian yang benar. Romadhina (dalam Hendriana,dkk,2017,hal.31) merinci indikator kemampuan penalaran matematis sebagai berikut:(1)mengajukan dugaan, (2)melakukan manipulasi matematika, (3)menarik kesimpulan, menyusun bukti, memberikan alasan atau bukti terhadap kebenaran solusi, (4)menarik kesimpulan dari pernyataan, (5)memeriksa kesahihan suatu argument, (6)menemukan pola atau sifat dari gejala matematis untuk membuat generalisasi.

Oleh karena itu, dibutuhkan pembekaan mengenai teknik-teknik penalaran dan pembuktian matematika, serta penerapan strategi, pendekatan, model pembelajaran yang dapat mengatasi kesulitan-kesulitan tersebut, sehingga kemampuan penalaran mahasiswa dapat meningkat. Salah satu model pembelajaran yang dianggap mampu meningkatkan kemampuan penalaran dan pembuktian mahasiswa pada mata kuliah analisa real adalah model pembelajaran ARIAS. Model pembelajaran ARIAS memiliki lima komponen yang saling terkait dan mendukung satu sama lain. Komponen pertama model pembelajaran ARIAS adalah Assurance (percaya diri), yaitu berhubungan dengan sikap percaya diri, yakin akan berhasil atau yang berhubungan dengan harapan untuk berhasil (Keller dalam Rahman, 2014: hal. 187). Komponen yang kedua Relevance, yaitu berhubungan dengan kehidupan mahasiswa baik berupa pengalaman sekarang atau yang telah dimiliki maupun yang berhubungan dengan kebutuhan karir sekarang atau yang akan datang (Keller dalam Rahman, 2014: hal. 188). Komponen yang ketiga Interest, yaitu yang berhubungan dengan minat/perhatian mahasiswa. Menurut Callahan bahwa sesungguhnya belajar tidak terjadi tanpa ada minat/perhatian (Rahman, 2014, hal. 189). Selanjutnya Assessment adalah yang berhubungan dengan evaluasi mahasiswa. Evaluasi merupakan suatu bagian pokok dalam pembelajaran yang memberikan keuntungan bagi dosen dan mahasiswa. (Lefrancois dalam Rahman, 2014: hal. 190). Komponen yang terakhir Satisfaction, yaitu yang berhubungan dengan rasa puas, bangga atau hasil yang dicapai. Dalam teori belajar satisfaction adalah reinforcement (penguatan). mahasiswa yang telah berhasil menegerjakan atau mencapai sesuatu merasa bangga/puas atas keberhasilan tersebut. Keberhasilan dan kebanggan tersebut itu menjadi penguat bagi mahasiswa tersebut untuk mencapai keberhasilan berikutnya (Gagne dan Driscoll dalam Rahman,2014: hal. 191). Dari uraian di atas, maka penelitian ini membahas mengenai penerapan model 
pembelajaran ARIAS (Assurance, Relevance, Interest, Assessment, dan Satisfaction) untuk meningkatkan kemampuan penalaran mahasiswa pada mata kuliah analisa real.

\section{Metode Penelitian}

Jenis penelitian ini adalah penelitian tindakan kelas atau dikenal dengan classroom action research, di mana prosedur penelitian ini berlangsung secara siklis (Nurrahmah dan Suhendar, 2017, hal. 36). Penelitian ini terdiri dari dua siklus. Masing-masing siklus terdiri dari empat tahapan yaitu perencanaan, tindakan, analisis, dan refleksi. Penelitian ini diterapkan kepada mahasiswa semester 6 pendidikan matematika tahun akademik 2017/2018. Jumlah mahasiswa yang mengikuti mata kuliah analisa real di kelas ini sebanyak 30 orang. Sumber data dalam penelitian ini adalah mahasiswa, peneliti, dan satu orang observer .

Instrumen yang akan digunakan dalam penelitian ini adalah lembar tes yang diberikan pada setiap akhir siklus serta lembar observasi dan catatan lapangan. Teknik pengumpulan data dalam penelitian tindakan ini adalah: data tentang situasi pembelajaran pada saat dilaksanakan tindakan, data kemampuan penalaran mahasiswa diperoleh dengan memberikan tes pada setiap akhir siklus, data tentang refleksi serta perubahan-perubahan yang terjadi di kelas diperoleh dari hasil wawancara dengan mahasiswa, dokumentasi aktivitas mahasiswa di kelas yang diambil pada setiap siklus.

Proses analisis data dilakukan oleh peneliti dan observer yang terdiri atas analisis data pada saat pelaksanaan kegiatan dan analisis data yang sudah terkumpul. Analisis dilakukan dengan mengumpulkan data, data yang dikumpulkan dapat berupa data kuantitatif dan data kualitatif. Setelah itu mengelompokkan data dan mengubah data yang berupa kalimat-kalimat dan data-data tentang aktivitas-aktivitas peneliti dan mahasiswa menjadi kalimat bermakna dan ilmiah. Untuk mengecek keabsahan data, peneliti menggunakan sistem triangulasi, yaitu salah satu cara dalam mengumpulkan serta menyimpulkan data dengan hasil pengamatan tiga pihak yaitu: mahasiswa, peneliti dan observer. Triangulasi tersebut merupakan triangulasi penyidik karena hasil pengamatan ketiga pihak tersebut digunakan untuk pengecekan keabsahan data yang terkumpul pada setiap siklus.

\section{Hasil Penelitian dan Pembahasan}

\section{Hasil}

Kegiatan penelitian pendahuluan merupakan tahap awal yang dilakukan untuk mengetahui bagaimana pembelajaran pada mata kuliah analisa real biasa diterapkan. Pada tahap ini, peneliti melakukan wawancara dengan beberapa mahasiswa yang sedang mengambil mata kuliah tersebut. Berdasarkan hasil pengamatan dan wawancara dengan mahasiswa selama penelitian pendahuluan, diperoleh hasil sebagai berikut: (1)kemampuan penalaran mahasiswa yang masih rendah pada mata kuliah analisa real. Sebagian besar mahasiswa mendapat nilai C (Cukup) pada mata kuliah ini (berdasarkan arsip peneliti). Hal ini juga terlihat saat diadakan tes pendahuluan, rata-rata kemampuan penalaran mahasiswa pada mata kuliah analisa real adalah 60,5 (2) Mahasiswa masih kurang aktif terlibat dalam proses pembelajaran. Hal ini dapat dilihat ketika peneliti memberikan kesempatan kepada mahasiswa untuk menanyakan kembali apa yang kurang 
dipahami, mereka lebih banyak diam, (3) Mata kuliah analisa real masih dianggap sulit oleh mahasiswa karena tingkat abstrak yang sangat tinggi, sedangkan kemampuan penalaran mahasiswa masih lemah, (4)Dari hasil pengamatan dan wawancara tersebut, maka peneliti menyusun skenario dan rencana pembelajaran yang akan dilaksanakan. Tindakan akan dibagi menjadi 2 siklus dan akan membahas mengenai Barisan dan Deret Bilangan Real. Siklus I akan membahas tentang pengertian barisan dan limitnya, sifatsifat limit barisan, keterbatasan barisan, kemonotonan barisan dan kekonvergenan barisan. Siklus II mengenai pengertian deret bilangan real, kriteria kekonvergenan deret, uji konvergensi deret, deret alternating, dan deret pangkat.

Penelitian dilanjutkan ke siklus I dengan tahap urutan antara lain: perencanaan, pelaksanan, analisis, dan refleksi. Pada tahap perencanaan, dirancang penerapan model pembelajaran ARIAS dalam mata kuliah analisa real untuk pokok bahasan yang akan disampaikan pada siklus I adalah pengertian barisan dan limitnya, sifat-sifat limit barisan, keterbatasan barisan, kemonotonan barisan dan kekonvergenan barisan. Dilakukan pembagian kelompok di mana masing-masing kelompok harus mencari referensi lain, melakukan diskusi antar anggota kelompok belajar untuk memahami materi, dan mempresentasikan hasil diskusi. Materi, latihan, dan soal tes akhir siklus dibuat untuk mengetahui perkembangan kemampuan penalaranmahasiswa. Catatan lapangan dipersiapkan untuk mengetahui data tentang situasi pembelajaran pada saat dilaksanakan tindakan siklus I. Lembar wawancara dipersiapkan untuk mewawancarai mahasiswa agar dapat mengetahui pendapat mereka mengenai model pembelajaran ARIAS dalam mata kuliah analisa real.

Tahap pelaksanaan pada siklus I terdiri dari 2 kali pertemuan. Pertemuan pertama dengan sub pokok bahasan sifat-sifat limit barisan, keterbatasan barisan, kemonotonan barisan dan kekonvergenan barisan. Dan pertemuan kedua untuk pelaksanaan tes akhir siklus I serta wawancara. Selama kegiatan siklus I, peneliti dibantu oleh observer untuk melakukan pengamatan dan mencatat semua yang terjadi selama pelaksanaan di siklus I pada lembar observasi dan catatan lapangan (terlampir). Berdasarkan hasil catatan lapangan diperoleh informasi aktivitas yang dilakukan mahasiswa, keaktifan dan partisipasi dalam pembelajaran cukup baik, namun masih didominasi oleh beberapa mahasiswa saja. Dokumentasi aktivitas mahasiswa pada saat siklus I dapat dilihat pada gambar di bawah ini:

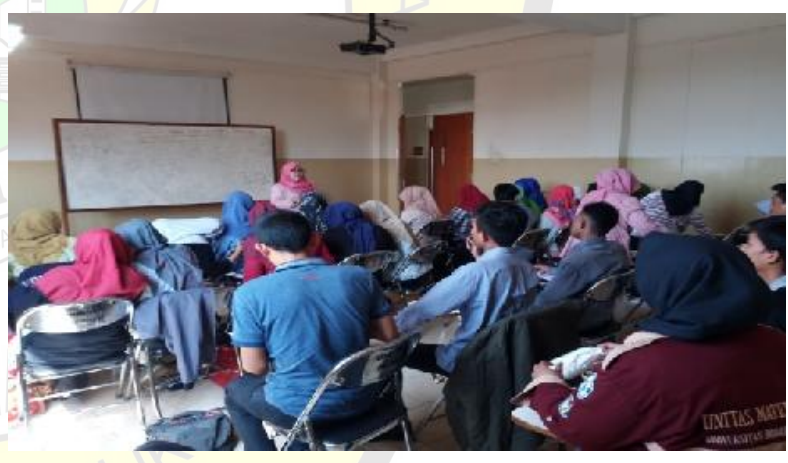

Gambar 1. Aktivitas Mahasiswa Pada Saat Kegiatan Siklus I

Pada siklus I sebagian besar mahasiswa sudah terlihat antusias dalam mengikuti pembelajaran ARIAS, terlihat saat berdiskusi sudah antusias walaupun ada beberapa yang terlihat kurang aktif. Pada pertemuan berikutnya, diadakan tes siklus I. Peneliti dibantu observer melakukan tes akhir siklus I dengan 3 soal essay. Berikut hasil tes akhir siklus I dapat dilihat pada tabel distribusi frekuensi di bawah ini: 
Tabel 1 Distribusi Frekuensi Nilai Tes Akhir Siklus I

\begin{tabular}{|c|c|c|c|}
\hline No. & $\begin{array}{c}\text { Kelas } \\
\text { Interval }\end{array}$ & $\begin{array}{l}\text { Frek } \\
\text { uensi }\end{array}$ & $\begin{array}{l}\text { Frekuensi } \\
\text { Relatif(\%) }\end{array}$ \\
\hline 1 & $50-56$ & 1 & 3,33 \\
\hline 2 & $57-63$ & 2 & 6,67 \\
\hline 3 & 64,70 & 9 & 30 \\
\hline 4 & $71-77$ & 10 & 33,33 \\
\hline 5 & $78-84$ & 4 & 13,33 \\
\hline 6 & $85-90$ & 4 & 13,33 \\
\hline \multicolumn{2}{|c|}{ Jumlah } & 30 & 100 \\
\hline
\end{tabular}

Berdasarkan hasil tes akhir siklus I menunjukkan bahwa nilai rata-rata mahasiswa memiliki rentangan nilai terendah 50 dan nilai tertinggi 87. Pada siklus I nilai rata-rata kemampuan penalaran yang didapatkan adalah 73,07. Nilai pertengahan (median) sebesar 71,20. Nilai modus sebesar 71,50. Nilai Varians (Var) sebesar 30,932 dan Standar Deviasi sebesar 5,56. Kemampuan penalaran yang didapat di siklus I ini sudah mengalami peningkatan jika dibandingkan dengan hasil pada tes pendahuluan, namun masih belum memenuhi indikator keberhasilan yang diharapkan karena masih ada beberapa mahasiswa yang mendapatkan nilai kurang (dibawah 56) yaitu sebanyak 1 orang dan nilai cukup (dibawah 68) sebanyak 5 orang. Oleh karena itu penelitian perlu dilanjutkan ke siklus II.

Peneliti juga melakukan wawancara terhadap tiga mahasiswa yang memiliki kemampuan tinggi, sedang, dan rendah pada pertemuan akhir siklus I. Kesimpulan yang didapatkan berdasarkan hasil wawancara pada siklus I adalah mahasiswa merasakan kepercayaan diri mereka sudah bertambah dengan pemberian model ARIAS. Selain itu dilakukan pula wawancara dengan observer sebagai bahan masukan pada siklus berikutnya. Kesimpulan yang didapatkan dari hasil wawancara dengan observer adalah perlu dioptimalkan semua tahap pembelajaran pada model ARIAS terutama pada tahap Assisment agar indikator yang diinginkan dapat tercapai.

Setelah melaksanakan pembelajaran pada siklus I, semua hasil pengamatan maupun hasil tes akhir yang didapatkan dianalisis untuk memperoleh gambaran bagaimana dampak dari tindakan yang sudah dilakukan, serta hal apa saja yang perlu diperbaiki. Dari hasil observasi, wawancara dan catatan lapangan ada beberapa masalah yang perlu diperbaiki pada siklus I, antara lain:

Tabel 2 Refleksi Tindakan Pembelajaran Pada Siklus I

\begin{tabular}{|c|c|c|}
\hline No. & Permasalahan & Rencana Perbaikan \\
\hline 3 & 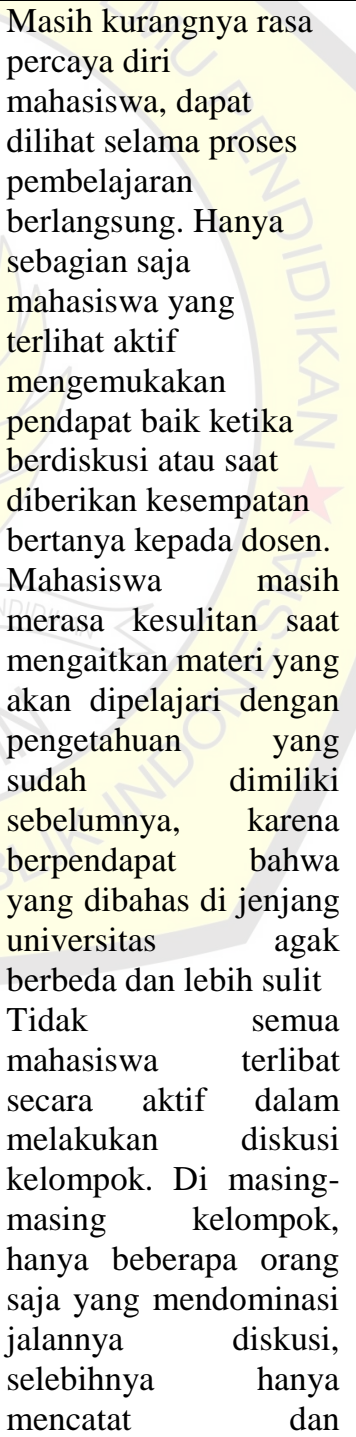 & $\begin{array}{l}\text { Mengingatkan } \\
\text { kembali dengan } \\
\text { memberikan motivasi } \\
\text { bahwa hakikatnya } \\
\text { mahasiswa berbeda } \\
\text { dengan siswa. } \\
\text { mahasiswa harus } \\
\text { mampu dan memiliki } \\
\text { kesadaran belajar } \\
\text { secara mandiri dan } \\
\text { berani } \\
\text { mengemukakan } \\
\text { pendapat dalam } \\
\text { diskusi kelompok. } \\
\text { Memberikan } \\
\text { bimbingan kepada } \\
\text { mahasiswa dalam } \\
\text { mencari referensi lain } \\
\text { sebagai bahan belajar, } \\
\text { misal judul buku atau } \\
\text { media pembelajaran } \\
\text { lain yang relevan } \\
\text { dengan materi yang } \\
\text { diajarkan untuk } \\
\text { pertemuan selanjutnya } \\
\text { Memberikan reward } \\
\text { kepada kelompok } \\
\text { yang seluruh anggota } \\
\text { kelompoknnya terlibat } \\
\text { aktif selama diskusi } \\
\text { berlangsung, dan } \\
\text { penilaian dimasukan } \\
\text { sebagai tambahan ke } \\
\text { dalam nilai tugas. }\end{array}$ \\
\hline
\end{tabular}


Berdasarkan hasil refleksi tindakan pembelajaran pada siklus I maka perlu dilanjukan tindakan pada siklus berikutnya dengan hasil refleksi siklus I digunakan sebagai bahan perbaikan. Untuk menyelesaikan masalah yang muncul berdasarkan hasil analisis dan refleksi yang dilakukan di siklus I, maka dirancang penerapan model pembelajaran ARIAS dalam mata kuliah analisa real yang mengacu pada hasil obeservasi siklus I.

Untuk menyelesaikan masalah yang muncul berdasarkan hasil analisis dan refleksi yang dilakukan di siklus I, maka dirancang penerapan model pembelajaran ARIAS dalam mata kuliah analisa real yang mengacu pada hasil observasi siklus I. Pada siklus II ini, peneliti mengoptimalkan kegiatan pada setiap tahapan pembelajaran ARIAS sehingga indikator keberhasilan pembelajaran ARIAS dapat tercapai dan hasil yang didapatkan lebih baik daripada di siklus I. Materi analisa real pada siklus II ini mengenai pokok bahasan deret bilangan real, pengertian deret bilangan real, kriteria kekonvergenan deret, uji konvergensi deret dan deret alternating. Adapun yang perlu disiapkan untuk pembelajaran siklus II adalah powerpoint materi, lembar kerja mahasiswa, tugas kelompok, soal tes akhir siklus II, lembar observasi, format wawancara, catatan lapangan, dan alat dokumentasi. Di siklus II ini diharapkan pembelajaran ARIAS dapat berjalan dengan baik dan kemampuan penalaran mahasiswa meningkat.

Tahap pelaksanaan pada siklus II terdiri dari 2 kali pertemuan. Pertemuan pertama dengan sub pokok bahasan deret bilangan real, pengertian deret bilangan real, kriteria kekonvergenan deret. Dan pertemuan kedua dengan sub pokok bahasan uji konvergensi deret, deret pangkat dan deret alternating. Untuk pelaksanaan tes akhir siklus II serta wawancara dilakukan pada pertemuan berikutnya. Selama kegiatan siklus II, peneliti dibantu oleh observer untuk melakukan pengamatan pada saat pelaksanaan siklus II. Berdasarkan hasil catatan lapangan diperoleh informasi aktivitas yang dilakukan mahasiswa, keaktifan dan partisipasi dalam pembelajaran sudah baik dan mengalami peningkatan dibandingkan siklus I. Seluruh indikator keberhasilan di setiap tahap pembelajaran ARIAS yang ditetapkan sebelumnya sebagai bahan acuan, sudah tercapai. Kepercayaan diri seluruh mahasiswa sudah tumbuh di siklus II ini. Hal ini terlihat dari hasil pengamatan bahwa seluruh mahasiswa sudah berani mengungkapkan pendapat saat di kelompok, mengajukan pertanyaan, atau menjawab pertanyaan yang diajukan oleh dosen. Dokumentasi aktivitas mahasiswa pada saat diskusi kelompok dapat dilihat pada gambar di bawah ini:

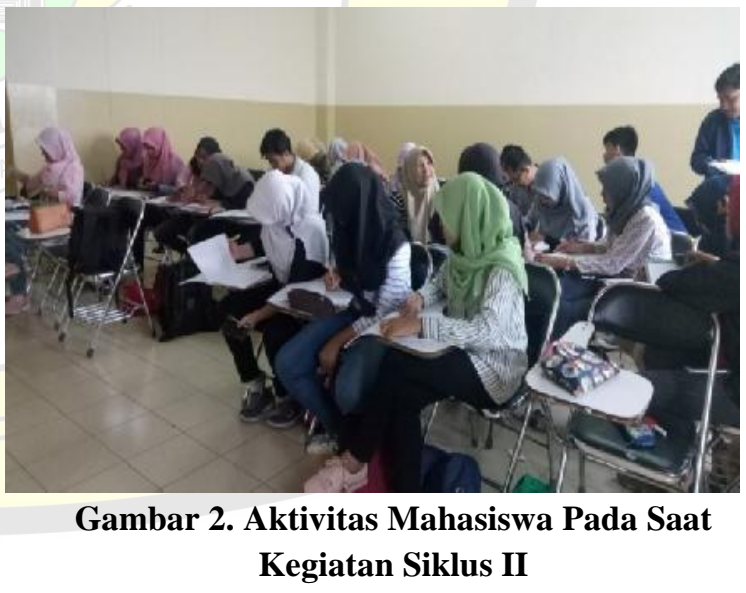

Pada siklus II sebagian besar mahasiswa sudah terlihat antusias dalam mengikuti pembelajaran ARIAS, terlihat saat berdiskusi sudah antusias dan terlibat secara aktif untuk mengemukakan pendapat maupun dalam membahas tugas yang diberikan. Pada pertemuan berikutnya, diadakan tes siklus II. Peneliti dibantu observer melakukan tes akhir 
siklus II dengan 6 soal essay. Berikut hasil tes akhir siklus II dapat dilihat pada tabel distribusi frekuensi di bawah ini:

Tabel 3 Distribusi Frekuensi Nilai Tes Akhir Siklus II

\begin{tabular}{cccc}
\hline No. & $\begin{array}{c}\text { Kelas } \\
\text { Interval }\end{array}$ & $\begin{array}{c}\text { Frek } \\
\text { uensi }\end{array}$ & $\begin{array}{c}\text { Frekuensi } \\
\text { Relatif(\%) }\end{array}$ \\
\hline 1 & $72-75$ & 6 & 20 \\
2 & $76-79$ & 5 & 16,67 \\
3 & $80-83$ & 8 & 26,67 \\
4 & $84-87$ & 4 & 13,33 \\
5 & $88-91$ & 1 & 3,33 \\
6 & $92-95$ & 6 & 20 \\
& Jumlah & 30 & 100 \\
\hline
\end{tabular}

Berdasarkan tabel 3 di atas, hasil tes akhir siklus II menunjukkan bahwa nilai ratarata mahasiswa memiliki rentangan nilai terendah 72 dan nilai tertinggi 95. Pada siklus II nilai rata-rata kemampuan penalaranyang didapatkan adalah 82,43. Nilai pertengahan (median) sebesar 81,5. Nilai modus sebesar 81,21. Nilai Varians (Var) sebesar 9,89 dan Standar Deviasi sebesar 3,14. Jika dibandingkan dengan siklus II, nilai rata-rata kemampuan penalaran mahasiswa sudah mengalami peningkatan. Tidak ada mahasiswa yang mendapatkan nilai kurang bahkan cukup, bahkan memiliki kemampuan penalaran dengan kategori Baik (B) hingga Amat Baik (A). Jika dilihat dari peningkatan nilai rata-rata tersebut maka indikator keberhasilan penelitian sudah tercapai.

Secara keseluruhan kemampuan penalaran mahasiswa pada mata kuliah analisa real jika dilihat dari nilai rata-rata tes setiap akhir siklus mengalami peningkatan. Sama halnya seperti di siklus I, peneliti juga melakukan wawancara terhadap tiga mahasiswa yang memiliki kemampuan tinggi, sedang, dan rendah pada pertemuan akhir siklus II. Kesimpulan yang didapatkan berdasarkan hasil wawancara pada siklus II adalah pemberian model pembelajaran ARIAS sudah baik, dan semua indikator pada tahap pembelajaran ARIAS sudah terlaksana. Demikian pula saat dilakukan wawancara dengan observer. Kesimpulan yang didapatkan dari hasil wawancara dengan observer adalah semua tahap pembelajaran pada model ARIAS sudah optimal dan berjalan dengan baik sehingga kemampuan penalaran mahasiswa pada mata kuliah analisa real juga meningkat.

Setelah melaksanakan pembelajaran pada siklus II, semua hasil pengamatan maupun hasil tes akhir yang didapatkan dianalisis untuk memperoleh gambaran bagaimana dampak dari tindakan yang sudah dilakukan. Dari hasil observasi, wawancara dan catatan lapangan, diperoleh hasil analisis refleksi yaitu pembelajaran mata kuliah analisa real dengan menerapkan model pembelajaran ARIAS berjalan dengan baik dan sesuai dengan yang diharapkan dibanding siklus sebelumnya. Seluruh indikator capaian keberhasilan pelaksanaan pada tahapan pada model pembelajaran ARIAS sudah terpenuhi. Hal ini berakibat pada kemampuan penalaran mahasiswa pada tes akhir siklus II sudah mendapatkan nilai B (Baik) hingga A( Amat Baik). Setelah mengidentifikasi dan menganalisis seluruh kegiatan refleksi siklus II, maka penelitian ini hanya dibatasi sampai siklus II karena tujuan penelitian secara umum telah tercapai yaitu meningkatkan kemampuan penalaran matematis mahasiswa pada mata kuliah analisa real melalui penerapan model pembelajaran ARIAS.

\section{Pembahasan}

Kegiatan penelitian yang sudah terlaksana mulai dari penelitian pendahuluan, siklus I sampai siklus II memiliki ciri masingmasing. Perbedaan dari tiap proses merupakan 
upaya untuk meningkatkan kemampuan penalaran mahasiswa pada analisa real dengan menerapkan model pembelajaran ARIAS. Pada siklus I, berdasarkan hasil pengamatan yang sudah dilakukan, diperoleh data bahwa masih kurangnya rasa percaya diri mahasiswa, dapat dilihat selama proses pembelajaran berlangsung. Hanya sebagian saja mahasiswa yang terlihat aktif mengemukakan pendapat baik ketika berdiskusi atau saat diberikan kesempatan bertanya kepada dosen. Menurut Tayibu (2018:13) "hal ini dikarenakan mahasiswa belum terbiasa dengan metode pembelajaran yang diterapkan. Pada siklus I ini Mahasiswa masih merasa kesulitan saat mengaitkan materi yang akan dipelajari dengan pengetahuan yang sudah dimiliki sebelumnya, karena berpendapat bahwa yang dibahas di jenjang universitas agak berbeda dan lebih sulit, serta tidak semua mahasiswa terlibat secara aktif dalam melakukan diskusi kelompok. Di masing-masing kelompok, hanya beberapa orang saja yang mendominasi jalannya diskusi, selebihnya hanya mencatat dan menunggu hasil diskusi.

Berdasarkan hasil catatan lapangan, diperoleh pada siklus II aktivitas yang dilakukan mahasiswa, keaktifan dan partisipasi dalam pembelajaran sudah baik dan mengalami peningkatan dibandingkan siklus I. Seluruh indikator keberhasilan di setiap tahap pembelajaran ARIAS yang ditetapkan sebelumnya sebagai bahan acuan, sudah tercapai. Kepercayaan diri seluruh mahasiswa sudah tumbuh di siklus II ini. Hal ini terlihat dari hasil pengamatan bahwa seluruh mahasiswa sudah berani mengungkapkan pendapat, mengajukan pertanyaan, atau menjawab pertanyaan yang diajukan oleh dosen.

Sejalan dengan makin optimalnya semua indikator yang ada pada tahap pembelajaran ARIAS, maka kemampuan penalaran mahasiswa pada mata kuliah analisa real juga mengalami peningkatan. Peningkatan yang terjadi dapat dilihat dari perolehan nilai rata-rata pada tes akhir siklus. Berdasarkan hasil tes akhir siklus I menunjukkan bahwa nilai rata-rata mahasiswa memiliki retangan nilai terendah 50 dan nilai tertinggi 87. Pada siklus I nilai rata-rata kemampuan penalaran yang didapatkan adalah 73,07. Kemampuan penalaran yang didapat di siklus I ini sudah mengalami peningkatan jika dibandingkan dengan hasil pada tes pendahuluan. Hasil tes akhir siklus II nilai rata-rata kemampuan penalaran yang didapatkan adalah 82,43.

Jika dibandingkan dengan siklus I, nilai rata-rata kemampuan penalaran mahasiswa pada mata kuliah analisa real sudah mengalami peningkatan. Tidak ada mahasiswa yang mendapatkan nilai kurang dan cukup, bahkan memiliki kemampuan penalaran dengan kategori Baik (B) hingga Amat Baik (A). Jika dilihat dari peningkatan nilai rata-rata tersebut maka indikator keberhasilan penelitian sudah tercapai. Dilihat secara keseluruhan setelah penerapan tindakan kelas mulai dari siklus I hingga siklus II, dengan menerapkan model pembelajaran ARIAS dapat meningkatkan kemampuan penalaran matematis mahasiswa pada mata kuliah analisa real. Hal ini terjadi karena pada model pembelajaran ARIAS memiliki adanya perbedaan perlakuan pada langkah pembelajaran, sehingga interaksi antara mahasiswa dengan mahasiswa ataupun mahasiswa dengan dosen berlangsung dengan baik. Hal ini sesuai dengan saran yang diungkapkan pada penelitian sebelumnya yang dilakukan oleh Wahyuni, dkk (2017:240) bahwa untuk mengatasi rendahnya kemampuan pemahaman dan penalaran matematis mahasiswa dosen dapat melakukan inovasi dalam pembelajaran matematika 
seperti menerapkan suatu model pembelajaran inovatif. Salah satunya adalah dengan menerapkan model pembelajaran ARIAS.

Model Pembelajaran ARIAS yang memiliki lima tahap pembelajaran yaitu Assurance, Relevance, Interest, Assesment, dan Satisfaction merupakan komponen yang saling terkait satu sama lain. Sesuai dengan pendapat Juhayla,dkk (2013:129) yang mengatakan bahwa pelaksanaan pembelajaran ARIAS dilakukan melalui tahap (1) Assurance; (2) Relevance; (3) Interest; (4) Assesment; (5) Satisfaction. Tahapan-tahapan tersebut bukan merupakan urutan, tetapi merupakan komponen-komponen yang saling menguatkan satu sama lain. Model pembelajaran ARIAS dikembangkan sebagai salah satu alternatif yang dapat diterapkan sebagai dasar pelaksanaan kegiatan pembelajaran dengan baik.

\section{Simpulan dan Saran}

\section{Simpulan}

Berdasarkan hasil penelitian dan pembahasan di atas maka disimpulkan bahwa penerapan model pembelajaran ARIAS dalam mata kuliah analisa real dengan menerapkan lima komponen yang saling terkait dan menguatkan satu sama lain, yaitu Assurance, Relevance, Interest, Assesment, dan Satisfaction, dapat meningkatkan kemampuan penalaran mahasiswa pada mata kuliah analisa real. Hal ini dapat dilihat dari peningkatan nilai rata-rata tes kemampuan penalaran mahasiswa pada penelitian pendahuluan hingga siklus II. Pada tes pendahuluan rata-rata kemampuan penalaran mahasiswa adalah 60,50, pada siklus I rata-rata kemampuan penalaran mahasiswa adalah 73,07, siklus II rata-rata kemampuan penalaran mahasiswa mengalami peningkatan menjadi 82,43 Berdasarkan hasil pengamatan dapat disimpulkan bahwa kelima komponen pada model pembelajaran ARIAS sudah berjalan dengan baik. Kepercayaan diri mahasiswa meningkat, mahasiswa mengetahui tujuan dan manfaat dari pokok bahasan yang dipelajari serta mengetahui aplikasi dalam kehidupan sehari-hari. Meningkatnya minat mahasiswa terhadap mata kuliah analisa real sehingga mahasiswa terlibat secara aktif dalam proses pembelajaran. Mahasiswa mampu memberikan penilaian terhadap diri sendiri dan teman lainnya atas tugas yang diberikan sehingga timbul rasa bangga dan puas atas hasil yang didapatkan.

\section{Saran}

Dalam upaya meningkatkan kemampuan penalaran mahasiswa dengan penerapan model pembelajaran ARIAS, saransaran berikut diharapkan berguna bagi yang ingin menerapkannya di dalam kelas: (1) Dosen diharapkan dapat membangkitkan semangat mahasiswa dalam belajar dan menciptakan persaingan yang sehat di antara mahasiswa untuk meningkatkan aktivitas dalam proses pembelajaran; (2) Bagi dosen hendaknya lebih inovatif dalam merancang dan melaksanakan kegiatan pembelajaran dengan menerapkan suatu model pembelajaran yang relevan untuk dapat meningkatkan kemampuan penalaran mahasiswa; (3)Bagi peneliti lain yang berminat untuk meneliti lebih lanjut model pembelajaran ARIAS, disarankan untuk lebih mengoptimalkan kelima tahapan yang terdapat pada model pembelajaran ARIAS serta dapat mengkolaborasikan dengan metode dan strategi pembelajaran lain sehingga didapat hasil penelitian yang lebih baik. 


\section{Daftar Pustaka}

Hernadi, Julan. (2015). Analisa Real Elementer Jakarta: Erlangga.

Juhayla,dkk. (2013). Penerapan Model Pembelajaran ARIAS (Assurance, Relevance, Interest, Assesment, Satisfaction) untuk Mengurangi Kesalahan Menyelesaikan Soal Keliling dan Luas Bangun Datar Siswa Kelas X SMK Negeri 1 Jember Tahun Ajaran 2012/2013. Jurnal Kadikma, Vol 4(3),121-130.

Karim, Abdul dan Arfatin Nurrahmah (2018).

Belajar Matematika Mengasikkan dan Bermakna Dengan Pendekatan Contexstual Teaching and Learning (CTL). Prosiding Diskusi Panel Nasional Pendidikan Matematika 2018. 98-106.

Karim, A. (2018). Analisis Kualitas Soal Perlombaan Matematika Tingkat SMA. Titian Ilmu: Jurnal Ilmiah Multi Sciences, 10(1), 1-8.

Nurrahmah, Arfatin dan Suhendar, Ayi Mumuh. (2017). Peningkatan Hasil Belajar Matematika dengan Menggunakan Lembar Kerja Siswa (LKS) dan Kartu Keaktifan Siswa (KKS). JKPM Vol 03 (1),34-45.

Rahman, Muhammat dan Sofan Amri. (2014). Model Pembelajaran ARIAS Terintegratif. Jakarta:PT. Prestasi Pustakaraya.

Sucipto, Lalu dan Mauliddin. (2016). Analisis Kesulitan Mahasiswa dalam Memahami Konsep Bilangan Real. Jurnal Tadris Matematika Vol.9 (2), 197-211.

Tayibu, N. Q. (2018). Penerapan Model Pembelajaran Arias (Assurance, Relevance, Interest, Assesment, Satisfaction) Untuk Meningkatkan Motivasi Belajar Matematika Siswa.

Wahyuni, dkk. (2017). Analisis Kemampuan Pemahaman dan Penalaran Matematis Mahasiswa Tingkat IV Materi Sistem
Bilangan Kompleks Pada Mata Kuliah Analisis Kompleks. Jurnal JNPM (Jurnal Nasional Pendidikan Matematika) Vol.1 (2), 228-240. 